UDC 791.9

DOI https://doi.org/10.24919/2308-4863/36-1-30

\section{Zhanna ANTIPOVA, \\ orcid.org/0000-0002-3052-0862 \\ Senior Lecturer at the Department of Physical Education National University "Odessa Law Academy" (Odessa,Ukraine) antipova195151@gmail.com}

Tatiana BARSUKOVA, Senior Lecturer at the Department of Physical Education National University "Odessa Law Academy" (Odessa,Ukraine) barsukova1507@gmail.com

Olga ADEEVA,

Candidate of Pedagogical Sciences, Associate Professor at the Department of Physical Education and Sports Odesa I. I. Mechnikov National University (Odessa, Ukraine) oadeeva1909@gmail.com

\title{
CHERLING AS A MEANS OF PHYSICAL EDUCATION AND HEALTH PRESERVATION OF STUDENTS OF HIGHER EDUCATION INSTITUTIONS
}

The article discusses the issue of introducing cheerleading into the educational process of physical education in legal institutions of higher education, its impact on physical fitness and mental performance of students. The data of physical readiness of first-year students are analyzed, a variant of solving the problem of forming a sustainable interest in them to physical culture and sports, to a healthy lifestyle is proposed. The role of physical fitness has been determined, which contributes not only to strengthening health and increasing working capacity, but also creates the preconditions for successful, in the future, professional activity, manifested in it through the state of health, the degree of physical fitness, adaptation to new life conditions.

To talk about the need to assess the level of physical fitness of students at the end of the semester and for the year, taking into account the individual characteristics of each student, which is an effective factor in increasing activity and a means in solving one of the most common problems of physical education - the formation of motivation for classes (Syomova, 2018: 28).

It is emphasized that the introduction of new methods and innovative technologies into the educational process will contribute to the formation of the necessary motivation of students to engage in all types of physical activity and maintain a healthy lifestyle.

Based on the works of the authors S. A. Nosikova, T. N. Galkina, N. Yu. Borisova on this problem, on the results of the testing and assessment of the level of physical fitness of students, the content of physical education classes was corrected. A special cheerleading program was introduced into the general physical education program, and guidelines for it were developed and proposed. This proposal contributed to the successful implementation of all the tasks of education in higher education.

Key words: physical education, physical fitness, students, motivation, healthy lifestyle, institutions of higher education.

Жанна АНТІПОВА, orcid.org/0000-0002-3052-0862 стариий викладач кафедри фізичного виховання Начіонального університету «Одеська юридична академія» (Oдеса, Україна) antipova195151@gmail.com

Тетяна БАРСУКОВА, orcid.org/0000-0002-1370-4475 старший викладач кафедри фізичного виховання Національного університету «Одеська юридична академія» (Oдеса, Україна) barsukova1507@gmail.com

Ольга АДЕЕВА, orcid.org/0000-0001-8146-017X кандидат педагогічних наук, дочент кафедри фізичного виховання і спорту Одеського начіонального університету імені I. I. Мечникова (Oдеса, Україна) oadeeva1909@gmail.com 


\section{ЧЕРЛІДИНГ ЯК ЗАСІБ ФІЗИЧНОГО ВИХОВАННЯ ТА ЗБЕРЕЖЕННЯ ЗДОРОВ'Я СТУДЕНТІВ ЗАКЛАДІВ ВИЩОЇ ОСВІТИ}

У статті розглядається питання введення черлідингу в навчальний процес з фізичного виховання в юридичних закладах вищої освіти, його вплив на фізичну підготовленість і розумову працездатність студентів. Проаналізовано дані фізичної підготовленості студентів периого курсу, запропоновано варіант вирішення проблеми з формування стійкого інтересу в них до занять фізичною культурою і спортом, до здорового способу життя. Визначено роль фізичної підготовленості, яка сприяє не тільки змічненню здоров'я та підвищенню працездатності, а й створює передумови для успішної в майбутньому професійної діяльності, проявляючись у ній через стан здоров'я, ступінь фізичної тренованості, адаптацію до нових життєвих умов.

Говориться про необхідність оцінювання рівня фізичної підготовленості студентів у кіниі семестру й за рік з урахуванням індивідуальних особливостей кожного студента, щзо є дієвим фактором підвищення активності й засобом у вирішенні однієї з найбільш поширених проблем фізичного виховання - формування мотивації до занять (Съёмова, 2018: 28).

Підкреслюеться, щзо введення в навчальний процес нових методів та інноваційних технологій сприятиме формуванню необхіної мотивації студентів до занять всіма видами рухової активності й ведення здорового способу життя.

Спираючись на роботи авторів С. А. Носикової, Т. Н. Галкіної, Н. Ю. Борисової із иієї проблеми, на результати проведеного тестування й оцінку рівня фізичної підготовленості студентів, зробили корекиію змісту занять з фізичного виховання. У загальну програму з фізичного виховання було запроваджено спеціальну програму з черлідингу, розроблено та запропоновано методичні рекомендації до неї. Така пропозиція сприяла успішній реалізації всіх поставлених завдань навчання у вищій школі.

Ключові слова: фізичне виховання, фізична підготовленість, студенти, мотивація, здоровий спосіб життя, заклади вищзої освіти.

Formulation of the problem. Today, technological progress, the rapid development of science and an increasing amount of new information that is necessary for a modern young specialist are noted, therefore, the student's educational activity is becoming more and more intense and intense. As a result, during the period of study, many specialists and scientists record a deterioration in the health status of student youth, which is considered as a problem of modern society.

The decrease in the level of health of student youth is indicated by the studies of the authors A. O. Dragich, V. A. Nikiforov, T. G. Pertseva, A. A. Nikiforova and others (Dragich, 2006: 396), (Nikiforov, Pertseva, Nikiforova; 2011: 126).

Authors D. D. Aistrakhanov, G. V. Kurchatov, M. F. Gavrilyuk, O. L. Blagiy, A. Zakharina and others, analyzing the state of health of students in Ukraine, note that only $14 \%$ of students are practically healthy, $50 \%$ of students have functional deviations, and $35 \%$ of students have chronic diseases (Aistrakhanov, Kurchatov, (Gavrilyuk, 2008: 12), (Blagiy, Zakharina, 2008: 12).

Effective measures are needed to help preserve and strengthen the health of students. Hence, the role of physical education increases as a means of optimizing the life regime of students, preserving and improving their health, increasing working capacity throughout the entire period of training (Lyashenko, Tsoi, 2018: 34). Conscious motivation for exercising is also important here, which depends on the use of new, non-traditional types of physical activity. This type, today, is considered cheerleading, based on the synthesis of aerobics, sports dances, acrobatics, modern show programs (Galkina, Borisova, Rumyantseva, 2017: 23), (Korosteleva, 2016: 133).

Currently, cheerleading is a segment of the global sports and entertainment industry, which is actively developing in Ukraine as well. Cheerleading is an excellent means of aesthetic development and moral education of female students. The introduction of such classes into the curriculum gives an opportunity for the development of creativity, motor abilities, increasing the functional capabilities of the body, the formation of the necessary motor skills.

But here a problematic situation arises, which is based on the need of science and practice for knowledge about the use of cheerleading in the system of physical education of higher education institutions and the lack of information about the influence of this type of activity on the body of female students, therefore our research is of particular importance and necessity. The implementation of research is possible only through improving the quality of the educational process, which becomes especially significant, and the issue of introducing cheerleading means into the system of physical education classes is relevant and valuable.

The successful solution of the main task of higher legal education: the acquisition by students of professional knowledge based on a sufficient level of physical fitness can be successfully promoted by active attendance of cheerleading classes, which contribute to the early adaptation of students to the learning conditions in higher education institutions. For this 
purpose, the teachers of the Department of Physical Education have developed a special (adapted for students of our academy) cheerleading program. The program was approved at a meeting of the department and introduced as a section of the general program for physical education for 1 st year students.

Research analysis. In the works of the authors S. A. Nosikova, T. N. Galkina, N. Yu. Borisova, E. L. Rumyantseva, E. N. Korosteleva notes that "Cheerleading is a modern direction of physical education at a university", the use of which contributes to increasing students' motivation for regular physical education and sports.

S. G. Syomova, K. B. Korbin, R. Lindsay present the concepts of forming an integral personality in the process of upbringing by means of physical culture. In their works, they reveal the laws of the successful development of physical abilities and motor qualities of students, building their conscious motivation for classes.

E. V. Popov, O. V. Aniskavich argue that cheerleading increases the performance of college students.

N. V. Krivoruchko, I. P. Maslyak, I. N. Zhuravleva in their works, they investigated the influence of cheerleading on the development of strength among students and noted the positive result of the use of cheerleading in the development of physical qualities.

M. M. Bobyreva in his work "Elective" cheerleading "as one of the health-saving general educational technologies in a higher educational institution of medical profile" speaks about the effectiveness of the result of using cheerleading in the problem of preserving and strengthening the health of students.

Modern authors (M. M. Shubovich, E. A. Grineva, N. E. Bibikova, S. V. Kondrashkina, K. Olsen, S. Dahl) turn to the problem of health and research on health-saving technologies that must be used to prevent bad habits among student youth.

According to researchers A. Ribkovsky, V. Shigalevsky, N. Falkova and others, the level of physical fitness of students is the most important integral indicator of the readiness of young people for vocational training and further improvement in their chosen profession. They emphasize that it is necessary to change the target settings of physical education, paying more attention to the use of innovative techniques and teaching methods, as well as the use of special pedagogical technologies.

According to the authors R. Bizet, J. A. Johnson, R. S. Plotnikoff, A. E. Bauman, only targeted physical education allows solving the problems of preparing a physically strong generation, raising it hardened, healthy and ready to perform professional tasks. This confirms the relevance of our topic and the need for research in order to select the most effective ways to solve the problem of increasing the level of physical fitness of students.

At the beginning of the last century, the great teacher V. A. Sukhomlinsky noted that "sport becomes a means of education when it is everyone's favorite pastime". Developing this idea, we can assume that cheerleading, being a favorite pastime of students participating in the study, can be an effective tool in the formation of a harmonious and highly developed personality. Hence, cheerleading is the path to success and a healthy, active lifestyle.

Purpose. The purpose of our work is to determine the influence of cheerleading classes on the level of physical fitness of students, assessing fitness as a component of health and success in training.

Presentation of the main material. First of all, it is necessary to consider the participants of our research, to determine the list of exercises to achieve successful results according to the proposed program, their influence on the physical qualities, which determine the level of physical fitness of the trainees.

Our research was carried out on the basis of the National University "Odessa Law Academy" in three faculties: Judicial-Administrative, International Legal Relations, training of Prosecutors and Investigators. A total of 205 people (17-18 years old) enrolled in the 1st year.

During the 1st semester in physical education classes, which were held according to the schedule, special attention was paid to the development of physical qualities necessary to increase the level of physical fitness of students. The peculiarity of organizing lessons on teaching the basics of cheerleading (according to the developed methodology) involves the use of small loads to achieve a positive result. This technique makes it possible to perform synchronous elements at a slow, medium, and then at a fast pace, repeatedly changing the rhythm, style, level and plane when performing tasks, achieving artistry, musicality and coherence.

The program was developed in accordance with the requirements of the state standard of higher education, in accordance with the existing general recommendations and on the basis of the studied experience of teaching cheerleading in institutions of higher education, in secondary schools, in the Cheerleading Federation (Program of the author N. V. Borisenko "Cheerleading", KhNUGH named after A. N. Beketova, 2017; E. Yu. Sokolova, Center for Organizational Methodological Support of Physical Education, Moscow, 2012; A. V. Shusharina, R. F. Krasnodar Territory, 2011; Cheerleading 
Federation of Ukraine, studio "Brilliant", Kiev, 2010 year; Odessa Regional Cheerleading Federation, Odessa, 2016).

When developing the program, pedagogical principles were applied that are standard used in educational and educational activities with students of higher educational institutions: the principle of consciousness and activity; clarity and consistency; accessibility and customization; as well as other, new principles that reflect the specifics of physical education.

The novelty of the presented program lies in the fact that, on the basis of a differentiated approach to each student, a non-standard approach to training is proposed in the section of basic training for cheerleaders, which includes teaching the basic necessary skills.

Purpose of the program:

- To create conditions for the successful realization of the natural inclinations and creative potential of each student.

- To contribute to the formation of conscious motivation to engage in physical culture and sports.

- Provide the implementation of the formation of a moral-aesthetic and socially-competent personality.

- Popularization of Cheerleading.

The applied program contributes to the comprehensive development of the personality of students; aimed at training, education and development of physical qualities, increasing the level of physical fitness; on the formation of their stable motivation to lead a healthy lifestyle and on a conscious attitude to their health as a value.

The training program includes theoretical and practical sections. In the theoretical section: The history of cheerleading. Conversations about general and sports ethics. Safety briefing in the gym, at the stadium, on stage. Acquaintance with different directions of modern and sports dance.

In the practical section: General physical, special and special technical training.

In general physical training, complexes of general developmental physical and dance exercises (warm-up) are used. Exercises for the development of flexibility (various swings, bends, twists, lunges, circular movements in various planes); endurance (jumping rope, running at different speeds and duration); strength (stuffed balls, dumbbells, shock absorbents, partner resistance, aimed at developing the strength of the muscles of the arms, hands, shoulder girdle, abdominal press, back, legs); coordination of movements (acrobatic exercises, exercises in balance); quickness (running for short distances, shuttle running).

The special training includes marching exercises (rebuilding), dance training (dance compositions).

The special technical training includes strength exercises (acrobatic and special stances, somersaults, wheels), the basics of cheerleading (cheer-dance - a dance block using the basic elements of cheerleading), learning chants.

When summing up the results of the practical application of the cheerleading program, students must successfully pass the developed control tests, perform the studied movements and dance ligaments. The control takes into account the development of all sections of the program by students, and when setting the final grade, participation in demonstration performances for the faculty or as part of the national team of the academy in the events held during the academic year is taken into account.

The results of passing the tests in the experimental group were assessed according to the table in the qualitative, point assessment and percentage. The comparative characteristics were based on the baseline age norms according to statistics, taking the baseline level as $100 \%$ (Table 1).

Indicators of physical fitness of students showed that out of 205 students who took part in the research, the standards for the beginning of experimental classes were passed as follows:

11 people passed to the high level, which amounted to $5.3 \%$,

to a sufficient level -56 people, which amounted to $-27.3 \%$,

to the average level -98 people, which amounted to $-47.8 \%$,

Table 1

Evaluation scale of physical fitness

\begin{tabular}{|c|c|c|c|c|}
\hline \multirow{2}{*}{ Age } & \multirow{2}{*}{ Level preparedness } & \multicolumn{3}{|c|}{ Physical fitness assessment } \\
\cline { 3 - 5 } & & Percentage & Ballroom & High quality \\
\hline \multirow{3}{*}{$17-19$ years } & Tall & $100 \%-92 \%$ & 5 & Excellent rating \\
\cline { 2 - 5 } & Sufficient & $91 \%-80 \%$ & 4 & Good score \\
\cline { 2 - 5 } & Middle & $79 \%-38 \%$ & 3 & Satisfactory rating \\
\cline { 2 - 5 } & Low & $37 \%$ and below & 2 & Not delivered \\
\hline
\end{tabular}


to a low level -40 people, which amounted to $19.6 \%$.

Analyzing the indices of individual testing at the beginning of the experimental period, it was noted that the results were the lowest in the standards for endurance. To improve the data of this indicator, additional exercises for the development of endurance were introduced. The result, at the end of the experiment, showed that endurance indicators changed for the better by $30.2 \%$.

Comparative characteristics of the test results at the end of the experimental period showed significant positive changes in the indicators of physical fitness of students:

28 people passed to the high level, which amounted to $13.6 \%$ (it was $5.3 \%$ ),

to a sufficient level - 116 people, which amounted to $56.5 \%$ (it was $27.3 \%$ ),

to the average level - 39 students, which amounted to $19.0 \%$ (it was $47.8 \%$ ),

to a low level -22 people, which amounted to $11.3 \%$ (it was $19.6 \%$ ).

It seems to us that it is not entirely correct to assess a student only by passing control standards. The assessment should objectively reflect the degree of his progress: the measure of the student's efforts relative to himself, and not in comparison with the average statistics; be differentiated and depend on the initial level of physical fitness for each individual; the results of the quality of physical training should take into account the natural process of age development and the degree of its progress during systematic exercises. Such an assessment of physical fitness will increase the activity of those involved. The events held at the academy will allow everyone to take part in them, increasing both the mass and the need for physical education in general.

To study the need-motivational sphere of physical activity, satisfaction with the organization of physical education in the academy and attitude to a healthy lifestyle, a special questionnaire was conducted. The results showed us that, unfortunately, there is still a certain number of students who are not sufficiently aware of the social value of health, especially in the structure of their own life:

$75 \%$ of the respondents consider themselves athletes and athletes;

$48 \%$ of the students called their physical regimen in the daily regimen to maintain health sufficient, but at the same time, $25 \%$ of the students do an additional four hours a week;

$47 \%$ of students consider physical exercises of any orientation necessary for success in their future professional legal activities.
But to the question: "Do you do physical exercises on your own or some kind of sport? (if not, why not?)" students answered:

I am actively engaged $-35 \%$,

I get tired in class at the academy $-8.2 \%$,

I don't do it for health reasons $-17.3 \%$,

not enough money $-13.5 \%$,

I can't fight myself $-17 \%$,

I don't know where to do it $-9 \%$.

The answer in the paragraph "Your attitude to the introduction of cheerleading into physical education" allowed us to conclude that the use of cheerleading was positively received by students: $93 \%$ support the introduction of cheerleading, are completely satisfied with the classes, and 7\% answered that they did not care what to do, that they went to classes only for credit. And the holding of the final event of the academy in cheerleading in the form of competitions between faculties, based on the knowledge gained in the classroom, received $100 \%$ approval from all students and deans of faculties.

Based on the results of our experimental lessons and on the basis of the analysis of the questionnaires, we can conclude that the use of cheerleading effectively contributes to solving problems of general and special physical fitness of students, increasing their activity and popularizing this new kind of sport in the academy. The regulation of the content of classes, the reduction of mandatory regulatory requirements, the holding of mass sports events with the use of demonstrative performances by cheerleaders contributes to an increase in students' conscious motivation for physical education and their introduction to a healthy lifestyle.

Findings. A high level of physical fitness, good health, developed endurance and adaptation in a social environment are the conditions for achieving success in the professional activity of a lawyer. This level of performance can be achieved when reorganizing the educational process, using a special cheerleading program; and also when teaching students selfcontrol, conducting independent studies, showing him the way to health and a healthy lifestyle.

The conducted researches allow to assert about the high efficiency of using cheerleading means in the system of physical education of female students of the Law Academy. Learning special movements of cheerleading and demonstration performances contribute to an increase in the level of physical fitness of students, the formation of conscious activity. Cheerleading classes are not only interesting for students, they also have a positive effect on their psychophysical state and the level of readiness for future professional activities. 
For a deeper study of this issue, it is necessary to conduct research in the future, relying on our results, the experience of other teachers of higher education institutions in our country and abroad. It is necessary to study in more detail the effect of the influence of cheerleading on the development of physical qualities among students in order to increase their interest in physical culture and sports.

\section{BIBLIOGRAPHY}

1. Съёмова С. Г. Особенности физической подготовленности студентов в вузе. Физическая культура. Cпорт. Туризм. Двигательная рекреация. 2018. Т. 3. № 3. С. 28-32.

2. Драгич О. А. Сравнительный анализ функционального состояния организма студентов Уральского Федерального Округа. Вестник Крас. ГАУ. Вып.12. 2006. С. 391-396.

3. Никифорова В. А., Перцева Т. Г., Никифорова А. А. Медико-биологические аспекты формирования здоровья. Состояние окружающей среды и здоровья населения : сборник материал. III Междунар. науч.-практ. конф. 5-6 апр. Курган, 2011. С. 126-128.

4. Айстраханов Д. Д., Курчатов Г. В., Гаврилюк М. Ф. Узагальнені тенденції змін стану здоров’я дорослого населення України. Украӥна. Здоров’я нащії. 2008. № 1 (5). С. 12-19.

5. Благій О. Л., Захарина Є. А. Аналіз захворюваності студентів гуманітарних ВНЗ. Теорія і методика фізичного виховання і спорту. 2006. № 4. С. 8-12.

6. Ляшенко А. А., Цой В. Г. Роль физической культуры в укреплении студентов Оренбургского государственного медицинского университета. Молодой ученый. 2018. № 1 (187). С. 34-36.

7. Галкина Т. Н., Борисова Е. Л., Румянцева Е. Л. Черлидинг - современное направление занятий по физической культуре в вузе. Педагогика высшей школьы. 2017. № 1 (7). С. 23-25.

8. Коростелева Е. Н. Черлидинг как путь повышения мотивации к занятиям спортом студенческой молодежи. Физическое воспитание и студенческий спорт глазами студентов : сборник материалов II Всероссийской научно-практической конференции с международным участием, посвященной 85-летию КНИТУ-КАИ. Москва, 2016. C. $133-136$.

9. Антипова Ж. И., Барсукова Ж. И. Черлидинг в физическом воспитании студенток. Одеса : Гельветика, 2020. C. $459-461$.

10. Антипова Ж. И., Фидирко М. А. Воздействие физического воспитания на личность будущего юриста. Одеса : Фенікс, 2013. С. 762-764.

11. Антипова Ж. И., Фидирко М. А. Значение физического воспитания в развитии и укреплении здоровья студентов. Науковий простір: Актуальні питання, досягнення та інноващіi : збірник Міжнародн. наук.-практ.конф., 02.10.2020 р. Київ, 2020. Т. 2. С. 20-23.

12. Антипова Ж. И., Фидирко М. О. Сохранение и укрепление здоровья студентов. Состояние и жизненная практика в структуре профессионального образования: теория и практика : материалы Всеукраинской научнопрактической конференции. Запорожье, 2018. С. 239-241.

\section{REFERENCES}

1. S'yomova, S. G. Osobennosti fizicheskoy podgotovlennosti studentov v vuze [Features of physical fitness of students in the university]. Physical culture. Sport. Tourism. Motor recreation. 2018. T. 3, No. 3. pp. 28-32 [in Russian]. https:// cyberleninka.ru/article/n/osobennosti-fizicheskoy-podgotovlennosti-studentov-v-vuze.

2. Dragich O.A. Sravnitel'nyy analiz funktsional'nogo sostoyaniya organizma studentov Ural'skogo Federal'nogo Okruga [Comparative analysis of the functional state of the organism of students of the Ural Federal District] Messenger Krasnoyarsk State Agrarian University. Issue 12. 2006. pp. 391-396 [in Russian]. https://cyberleninka.ru/article/n/analizmorfofunktsionalnoy-izmenchivosti-organizma-studentov-urfo.

3. Nikiforova V.A., Pertseva T.G., Nikiforova A.A. Mediko-biologicheskiye aspekty formirovaniya zdorov'ya [Medical and biological aspects of health formation].State of the environment and public health: materials of the III international scientific and practical conference. Kurgan. 2011. pp. 126-128 [in Russian]. https://brstu.ru/static/unit/journal_smt/redkollnikiforova-v-a.php.

4. Aystrakhanov D.D. Obobshchennyye tendentsii izmeneniy sostoyaniya zdorov'ya vzroslogo naseleniya Ukrainy [Generalized tendencies of changes in the health status of the adult population of Ukraine] Ukraine. Health of the nation. 2008. No 1 (5). pp. 12-19 [in Ukrainian]. http://hnpu.edu.ua/sites/default/files/files/Kaf_zdor_ta_korr_os/Zagalna_teorija_ zdoro via_i_zdorviazberegennja.pdf.

5. Blagoy A.L Analiz zabolevayemosti studentov gumanitarnykh vuzov [Analysis of morbidity among students of humanitarian universities]. Theory and methods of physical education and sports.2006. No 4. pp. 8-12 [in Ukrainian]. https://scholar.google.com.ua/citations?user=Rmusm-cAAAAJ\&hl=ru.

6. Lyashenko, A.A. Rol' fizicheskoy kul'tury v ukreplenii studentov Orenburgskogo gosudarstvennogo meditsinskogo universiteta [The role of physical culture in strengthening students of the Orenburg State Medical University]. Young scientist. 2018. No. 1 (187). pp. 34-36 [in Russian]. https://moluch.ru/archive/187/47629/.

7. Galkina T.N., Borisova N.YU., Rumyantseva Ye.L. Cherliding - sovremennoye napravleniye zanyatiy po fizicheskoy kul'ture $\mathrm{v}$ vuze [Cheerleading is a modern direction of physical education at a university]. Pedagogy of higher education. 2017. No. 1 (7). pp. 23-25 [in Russian]. https://moluch.ru/th/3/archive/50/1756/. 
8. Korosteleva Ye.N. Cherliding kak put' povysheniya motivatsii k zanyatiyam sportom studencheskoy molodezhi [Cheerleading as a way to increase student youth motivation to go in for sports]. In the collection: PHYSICAL EDUCATION AND STUDENT SPORT IN THE EYES OF STUDENTS, materials of the II All-Russian scientific-practical conference with international participation, dedicated to the 85th anniversary of Kazan National Research Technical University KAI. 2016. pp. 133-136 [in Russian]. https://elibrary.ru/item.asp?id=28347830\&pf=1.

9. Antipova ZH.I., Barsukova T.A. Cherliding v fizicheskom vospitanii studentok [Cheerleading in the physical education of female students]. Odesa: Helvetika.2020. pp. 459-461 [in Ukrainian]. http://dspace.onua.edu.ua/bitstream/handle/.

10. Antipova ZH.I., Fidirko M.A. Vozdeystviye fizicheskogo vospitaniya na lichnost' budushchego yurista [The impact of physical education on the personality of the future lawyer]. Odessa. Fenix. 2013. pp. $762-764$ [in Ukrainian]. http://hdl. handle.net/11300/715.

11. Antipova ZH.I., Fidirko M.A. Znacheniye fizicheskogo vospitaniya v razvitii i ukreplenii zdorov'ya studentov [The importance of physical education in the development and strengthening of students' health]. Sciences practical conference. 02.10.2020, vol. 2. pp. 20-23 [in Ukrainian]. https://scholar.google.com.ua/citations?user=7hgyEYUAAAAJ\&hl=ru.

12. Antipova ZH.I., Fidirko M.O. Sokhraneniye i ukrepleniye zdorov'ya studentov [Preservation and strengthening of students' health]. All-Ukrainian scientific-practical conference "State and life practice in the structure of vocational education: theory and practice". Zaporozhye. May 17. 2018. pp. 239-241 [in Ukrainian]. https://scholar.google.com.ua/cita tions? user=7hgyEYUAAAAJ\&hl=ru. 